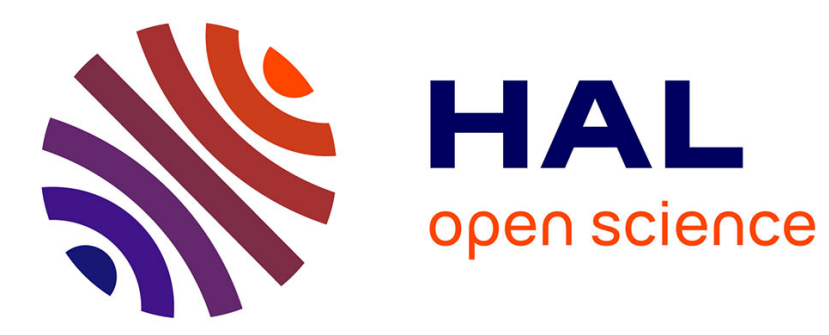

\title{
Recent warming inconsistent with natural association between temperature and atmospheric circulation over the last 2000 years
}

\author{
P. A. Mayewski, K. A. Maasch
}

\section{- To cite this version:}

P. A. Mayewski, K. A. Maasch. Recent warming inconsistent with natural association between temperature and atmospheric circulation over the last 2000 years. Climate of the Past Discussions, 2006, 2 (3), pp.327-355. hal-00298134

HAL Id: hal-00298134

https://hal.science/hal-00298134

Submitted on 30 Jun 2006

HAL is a multi-disciplinary open access archive for the deposit and dissemination of scientific research documents, whether they are published or not. The documents may come from teaching and research institutions in France or abroad, or from public or private research centers.
L'archive ouverte pluridisciplinaire HAL, est destinée au dépôt et à la diffusion de documents scientifiques de niveau recherche, publiés ou non, émanant des établissements d'enseignement et de recherche français ou étrangers, des laboratoires publics ou privés. 


\section{Recent warming inconsistent with natural association between temperature and atmospheric circulation over the last 2000 years}

\section{P. A. Mayewski and K. A. Maasch}

Climate Change Institute, Bryand Global Sciences Building, University of Maine, Orono, Maine 04469, USA

Received: 11 November 2005 - Accepted: 24 April 2006 - Published: 30 June 2006

Correspondence to: P. A. Mayewski (paul.mayewski@maine.edu)

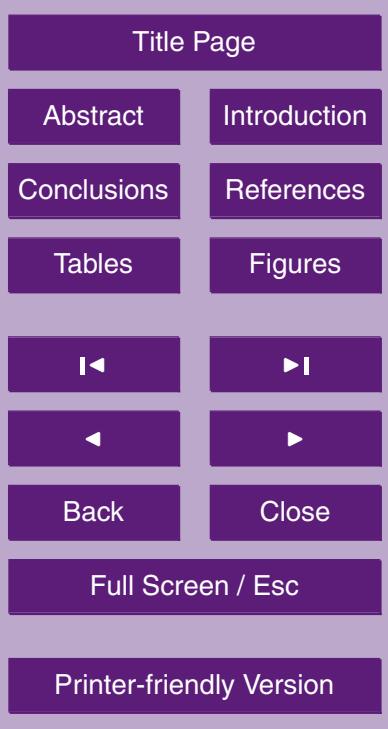

Interactive Discussion 


\section{Abstract}

Comparison between proxies for atmospheric circulation and temperature reveals associations over the last few decades that are inconsistent with those of the past 2000 years. Notably, patterns of middle to high latitude atmospheric circulation in both hemi5 spheres are still within the range of variability of the last 6-10 centuries while, as demonstrated by Mann and Jones (2003), Northern Hemisphere temperatures over recent decades are the highest of the last 2000 years. Further, recent temperature change precedes change in middle to high latitude atmospheric circulation unlike the two most notable changes in climate of the past 2000 years during which change in atmospheric circulation preceded or coincided with change in temperature. In addition, the most prominent change in Southern Hemisphere temperature and atmospheric circulation of the past 2000 , and probably 9000 years, precedes change in temperature and atmospheric circulation in the Northern Hemisphere unlike the recent change in Northern Hemisphere temperature that leads. These findings provide new verification that recent rise in temperature is inconsistent with natural climate variability and is most likely related to anthropogenic activity in the form of enhanced greenhouse gases.

From our investigation we conclude that the delayed warming over much of the Southern Hemisphere may be, in addition to other factors, a consequence of underpinning by natural climate variability. Further bipolar comparison of proxy records of atmospheric circulation demonstrates that change in atmospheric circulation in the Southern Hemisphere led by 400 years, the most abrupt change in Northern Hemisphere atmospheric circulation of the last 9000 years. This finding may be highly relevant to understanding a future when warming becomes more fully established in the Southern Hemisphere.
2, 327-355, 2006

Climate variability

over the last 2000

years

P. A. Mayewski and

K. A. Maasch

Title Page

Abstract

Introduction

Conclusions

References

Tables

Figures

14

4

Back

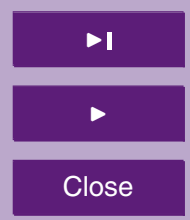

Full Screen / Esc

Printer-friendly Version

Interactive Discussion 


\section{Introduction}

Recent reductions in ice extent over the Arctic, Antarctic Peninsula, and for many midlow latitude glaciers demonstrate some of the initial impacts of rise in temperature over the last few decades (IPCC, 2001; ACIA, 2004). Reconstructions of past temperature 5 indicate that this rise is anomalous relative to temperature variability over the last 2000 years (e.g., Mann and Jones, 2003; Moberg et al., 2005). However, the association between change in temperature and change in atmospheric circulation under natural conditions has not been examined as vigorously. This association is perhaps most critical to investigate in the polar latitudes, where future warming is expected to be the greatest (IPCC, 2001). Synthesis of $\sim 50$ well-dated, continuous palaeoclimate records covering the current interglacial (the last $\sim 10000$ years, Holocene) reveals the occurrence of at least six periods of naturally forced abrupt climate change, of which several coincide with major disruptions in civilization (Mayewski et al., 2004). We focus here initially on the perspective gained from examination of the full Holocene record, followed is within the last 2000 years that annually resolved dating is most accurate and further this time period is characterized by boundary conditions (e.g., ice, ocean, atmosphere) most similar to those of today. Over this period established, well-dated, proxy records of change in temperature are available (e.g., Mann and Jones, 2003). For this period we select bipolar palaeoclimate records that provide proxy reconstructions of past changes in regional scale atmospheric circulation, a major component of the climate system that has not received the same detailed attention as that given to past temperature, despite a strong association with temperature over a wide range of timescales (Mayewski et al., 1997; Thompson and Wallace, 2000; Bertler et al., 2004; Masson-

Delmotte et al., 2005; Schneider et al., 2006). The records are well-dated, climatecalibrated ice cores from central Greenland (GISP2: $72.6^{\circ} \mathrm{N}, 38.5^{\circ} \mathrm{W} ; 3210 \mathrm{~m}$ a.s.I.) and from West Antarctica (Siple Dome (SD: $81.7^{\circ} \mathrm{S}, 148.8^{\circ} \mathrm{W} ; 621 \mathrm{~m}$ a.s.I.), (Fig. 1). These records reveal the behaviour of past atmospheric circulation in regions currently
2, 327-355, 2006

Climate variability over the last 2000 years

P. A. Mayewski and K. A. Maasch

Title Page

Abstract Introduction

Conclusions

Tables

References

Figures

14

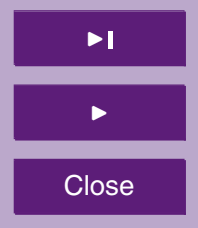

Back

Close

Full Screen / Esc

Printer-friendly Version

Interactive Discussion 
undergoing dramatic change due to warming (Arctic and Antarctic Peninsula) (ACIA, 2004; Turner et al., 2005) or expected in the near future to respond notably to warming based on observations and model results (Hansen et al., 2005; Barnett et al., 2005).

\section{Background to ice core reconstruction of past atmospheric circulation}

5 Polar ice core stable isotope ratios are commonly interpreted in terms of local temperature, on the basis of Rayleigh-fractionation models and positive spatial and temporal correlations with air and surface temperature (Noone and Simmonds, 2002; Werner and Heinmann, 2002). The palaeo-atmospheric reconstructions, developed from GISP2 and SD, are based on changes in the concentration of seasalts and dusts deposited at these ice core sites, derived, respectively, from the ocean and ice-free continents (Legrand and Mayewski et al., 1997). Flux calculations (annual ice accumulation rate times ion concentration) are not used in this study as previous investigations have shown that variations in ice accumulation on the annual scale are orthogonal (not statistically associated) with ion concentrations (Meese et al., 1994; Mulvaney and Unlike ice core stable isotope proxies for past temperature, ice core seasalt and dust series are statistically associated with the behaviour of regional and larger major atmospheric circulation systems (Kreutz et al., 2000; Meeker and Mayewski, 2002; Meyerson et al., 2002; Souney et al., 2002; Goodwin et al., 2004; Mayewski et al., 2004, 2006). Hence the comparison in this paper between the GISP2 and SD proxies for regional and larger scale atmospheric circulation (Fig. 1) and hemispheric reconstruction of past temperature developed from a synthesis of paleoclimate records (Mann and Jones, 2003).

2, 327-355, 2006

Climate variability over the last 2000

years

P. A. Mayewski and K. A. Maasch

Title Page

Abstract Introduction

Conclusions References

Tables Figures

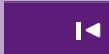

14 $\Delta$

4

Back Close Full Screen / Esc Printer-friendly Version

Interactive Discussion 


\subsection{Ice core dating}

For the past $\sim 100$ years the GISP2 and SD records are dated to $<1$ year error based on multi-parameter methods (chemistry, isotopes, electrical conductivity, stratigraphy) calibrated to volcanic and nuclear fallout events. GISP2 was sampled at more than 12

5 samples per year for the period AD 1879-1989 and SD over the period AD 1885-1995 at 6-12 samples per year. Over the remainder of the last 2000 years GISP2 and SD ice cores are sampled near bi-annually and dated to +/- 15 years (Meese et al., 1997; Taylor et al., 2004). Dating prior to the last 2000 years has significantly higher errors precluding detailed examination of bipolar phasing of climate at multi-decadal scales.

\subsection{Calibrating ice core reconstructions of past atmospheric circulation}

Concentrations of $\mathrm{Na}^{+}$in Greenland snow are strongly influenced by semi-permanent features of the winter surface pressure field in the North Atlantic based on comparison between GISP2 $\mathrm{Na}^{+}$and instrumental records covering the period AD 1899-1987 of atmospheric surface pressure (Trenberth and Paolino, 1980) over the North Atlantic 15 Meeker and Mayewski, 2002). Winters in which $\mathrm{Na}^{+}$concentrations are lowest exhibit high pressure anomalies in the region of the Atlantic's subpolar low (Icelandic Low, Fig. 1) and low anomalies in the region of the eastern extension of its subtropical high (Azores High). This pattern is reversed in winters in which $\mathrm{Na}^{+}$concentrations are highest with a deepening of the Icelandic Low. Comparison of the mean December-January-February (period of maximum $\mathrm{Na}^{+}$input to Greenland (Whitlow et al., 1992; Legrand and Mayewski, 1997) surface pressure fields for the 30 highest and 30 lowest $\mathrm{Na}^{+}$years shows that winters with high $\mathrm{Na}^{+}$deposition have a steeper pressure gradient (more than $8 \mathrm{mb}$ ). This is consistent with intensified winter circulation in the North Atlantic enhancing transport of $\mathrm{Na}^{+}$to central Greenland. EOF analysis reveals that $66 \%$ of the variance in $\mathrm{Na}^{+}$and the Icelandic Low series is represented by their common first EOF (negative correlation).Comparison between GISP2 $\mathrm{nssK}^{+}$and instrumental records covering the period AD 1899-1987 of atmospheric

Climate variability over the last 2000 years

P. A. Mayewski and K. A. Maasch

\section{Title Page}

Abstract Introduction

Conclusions

Tables

References

Figures

14

$\Delta$

4

Back

Close

Full Screen / Esc

Printer-friendly Version

Interactive Discussion 
surface pressure over Asia (Trenberth and Paolino, 1980) demonstrates that relative to years of low nssK ${ }^{+}$deposition, years with high $\mathrm{nssK}^{+}$deposition are associated with spring strengthening of the high over Siberia $(\sim 3 \mathrm{mb})$, the coldest air mass in the Northern Hemisphere, and deepening of the low over South Asia, during March-April-May 5 (Meeker and Mayewski, 2002) (the period of maximum input of nssK $^{+}$to Greenland (Whitlow et al., 1992; Legrand and Mayewski, 1997). It is unlikely that air masses on the south side of the Himalayas act as a source for nssK ${ }^{+}$to Greenland so Meeker and Mayewski (2002) focus on the Siberian High (Fig. 1) feature and assume that the South Asia association to $\mathrm{nssK}^{+}$is through a teleconnection with the Siberian High (Piexoto 10 and Oort, 1992). Potassium is transported in the finest range of Asian dust (Zhang et al., 1993) and long distance transport to Greenland from a $\mathrm{K}^{+}$- rich source, such as central Asia is highly probable. Asian sources for much of the dust deposited over Greenland are suggested from investigations of older portions of the GISP2 ice core (O'Brien et al., 1996; Biscaye et al., 1998). EOF analysis demonstrates that $\mathrm{nssK}^{+}$and 15 Siberian High series share $58 \%$ of their variance (positive correlation). Increased levels of GISP2 $\mathrm{nssCa}^{++}$are associated with the development of a high (more than $2 \mathrm{mb}$ ) over western Canada, reduction in the low over Greenland and weakening of the high over Northeastern Europe during September-October-November, the period of maximum input of nssCa ${ }^{++}$to Greenland (Whitlow et al., 1992; Legrand and Mayewski, 1997). 20 This may be indicative of the teleconnected behaviour induced by spatial patterns in the standing oscillations of planetary waves. This atmospheric configuration leads to transport of continental source $\mathrm{Ca}^{++}$to Greenland from western Canada through the Canadian Arctic. Since sources of $\mathrm{nssCa}^{++}$are readily available from all Northern Hemisphere continents overall transport is most likely via the westerlies (Fig. 1) (Mayewski et al., 2006). Previous work indicates that higher (lower) $\mathrm{Na}^{+}$concentrations in the SD ice core are coincident with higher (lower) levels of September-October-November cyclone intensity in one of the major quasi-stationary lows in the circumpolar trough, the Amundsen Sea Low (Fig. 1) (Kreutz et al., 2000). This timing is consistent with the seasonal maximum in $\mathrm{Na}^{+}$in Antarctic ice cores (Whitlow et al., 1992; Kreutz et al., 2000)

Climate variability over the last 2000 years

P. A. Mayewski and K. A. Maasch

\section{Title Page}

Abstract Conclusions

Tables References Figures

14

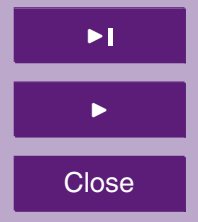

Back

Full Screen / Esc

Printer-friendly Version

Interactive Discussion 
and with sources of $\mathrm{Na}^{+}$from the sea surface (Legrand and Mayewski, 1997) and salt flowers (Hall and Wolff, 1998). The same association is demonstrated for ITASE (International Trans Antarctic Scientific Expedition) ice cores (Kaspari et al., 2005). Annual values of $\mathrm{Na}^{+}$in the Siple Dome ice core are correlated $(r=-0.32, \mathrm{P}<0.001$ (annual 5 series) and $r=-0.51, P<0.001$ (3-year smoothed series)) with September-OctoberNovember surface pressure changes over much of the South Pacific for the period AD 1900-1995 (Kreutz et al., 2000). For the period AD 1948-2002 and 1979-2002 negative anomalies close to $7 \mathrm{mb}$ in the region of the Amundsen Sea Low, as determined from the NCEP/NCAR reanalysis (Kalnay et al., 1996) (NOAA-CIRES Climate 10 Diagnostics Center, (http://www.colc.noaa.gov)) are associated with increased levels of Siple Dome $\mathrm{Na}^{+}$.Dust from Australia, Africa, and South America and sea-salt from the Southern Ocean are the primary sources for $\mathrm{Ca}^{2+}$ in West Antarctic ice cores. Changes in SD Ca ${ }^{++}$and in other West Antarctic ice cores collected as part of ITASE are correlated with changes in the September-October-November surface mean zonal 5 wind surrounding Antarctica (Fig. 1) available from the NCEP/NCAR reanalysis (Kalnay et al., 1996) ((NOAA-CIRES Climate Diagnostics Center, (http://www.colc.noaa.gov) most notably the region close to $40-50^{\circ} \mathrm{S}$ in the Indian and Pacific Oceans (Yan et al., 2005). This timing is consistent with the seasonal maximum in $\mathrm{Ca}^{++}$in Antarctic ice cores (Whitlow et al., 1992; Yan et al., 2005). Siple Dome and ITASE $\mathrm{Ca}^{++}$an20 nually averaged series are positively correlated $(r=0.38, P<0.01$ and $r=0.44, P<0.01$, respectively); 3-year smoothed series $(r=0.56, P<0.01$ and $r=0.75, P<0.01$, respectively) with the September-October-November surface circumpolar mean zonal wind over the period of NCEP/NCAR reanalysis coverage (AD 1948-2002 and 1979-2002) (Yan et al., 2005). Anomalies as high as $4 \mathrm{~m} / \mathrm{s}$ exist in regions where mean (AD 194825

2002 and 1979-2002) September-October-November winds are 8-12 m/s. From this correlation Yan et al. (2006) demonstrate that stronger (weaker) westerly winds are conducive to more (less) transport of crustal and marine source $\mathrm{Ca}^{++}$. Correlation between $\mathrm{Ca}^{++}$series and higher levels of zonal wind in the atmosphere $(500 \mathrm{mb})$ reveal a similar westerly wind influence (Yan et al., 2006).
2, 327-355, 2006

Climate variability

over the last 2000

years

P. A. Mayewski and

K. A. Maasch

Title Page

Abstract

Introduction

Conclusions

Tables

References

Figures

14

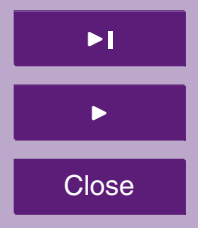

Back

Close

Full Screen / Esc

Printer-friendly Version

Interactive Discussion 


\section{Comparison of past atmospheric circulation and past temperature}

Previous research demonstrates that in general temperature and atmospheric circulation are associated as follows: cold (warm) associated with stormy (mild), throughout the Glacial and Holocene (Grootes and Stuiver, 1997; O'Brien et al., 1996; Mayewski 5 et al., 1997, 2004; Masson-Delmotte et al., 2005).

\subsection{The 9000-year perspective}

To set the stage for understanding the behaviour of atmospheric circulation systems in the middle to high latitudes over recent centuries to decades we examine the last 9000 years of the GISP2 and SD ice core proxies for past atmospheric circulation (Fig. 2). 10 GISP2 seasalts, represented by $\mathrm{Na}^{+}$, and dusts, represented by non-seasalt (nss) $\mathrm{K}^{+}$ and nss $\mathrm{Ca}^{++}$, display increases, coincident with periods of intensified atmospheric circulation and colder temperatures (Mayewski et al., 1997; O'Brien et al., 1996), consistent with the timing of abrupt climate change inferred from previous records (Denton and Karlén, 1973; Mayewski et al., 2004). Shaded portions of Fig. 2 coincide with 15 the identification of Holocene age rapid climate change events developed from the Mayewski et al. (2004) analysis of $\sim 50$ paleoclimate records. The most notable change of the last 9000 years (Fig. 2) in the GISP2 $\mathrm{Na}^{+}$and nssK ${ }^{+}$series is the abrupt transition from relatively mild conditions since $\sim 2400$ years ago and for the GISP2 $\mathrm{nssCa}^{++}$ since $\sim 5000$ years ago, to the period of greatest atmospheric circulation intensification

of the last 9000 years, notably AD 1400. At this time proxies for the Siberian High and Icelandic Low and shortly after the GISP2 proxy for Northern Hemisphere westerlies indicate dramatic intensification of atmospheric circulation throughout the high middle to polar latitudes of the Northern Hemisphere. The most notable change over the last 9000 years (Fig. 2) in the $\mathrm{SD} \mathrm{Na}{ }^{+}$and $\mathrm{Ca}^{++}$series is the transition from lower to ern Hemisphere westerlies by $\sim A D$ 1000. The SD record reveals fewer periods of abrupt climate change than those recorded at GISP2. An earlier period of atmospheric

2, 327-355, 2006

Climate variability over the last 2000

years

P. A. Mayewski and K. A. Maasch

Title Page

Abstract Introduction

Conclusions

Tables

References

Figures

14 - I

4

Back

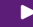

Close

Full Screen / Esc

Printer-friendly Version

Interactive Discussion 
circulation intensification, 5000-6000 years ago, is found in both the GISP2 and SD records.

\subsection{The 2000-year perspective}

During the last 2000 years of the pre-anthropogenic era two primary climate events, in 5 general, impacted the middle to high latitudes (e.g., Grove, 1988). These events occur during periods termed the Medieval Warm Period, when temperatures were similar to portions of the last century, but lower than the last one to two decades (Mann and Jones, 2003; Moberg et al., 2005), followed by an abrupt onset of conditions termed the Little Ice Age (onset nominally AD 1000-1400) when temperature was $\sim 1^{\circ} \mathrm{C}$ lower than today (Mann and Jones, 2003; Soon and Baliunas, 2003; Mayewski et al., 2004; Moberg et al., 2005). Although the climate change events recorded in the GISP2 and SD records of the last 2000 years coincide with the general timing of the Medieval Warm Period and the Little Ice Age we avoid using this terminology because change during these periods may have varied dramatically from region to region. We define climate change in this record based on the following.

Using Fig. 3 we define climate change events by comparing the association between temperature, utilizing the Mann and Jones (2003) Northern and Southern Hemisphere temperature reconstructions, and the ice core reconstructions of past atmospheric circulation (Fig. 1) noted earlier in the paper. The $<30-y r$ signal is removed from the 20 temperature and circulation series in Fig. 3 to allow comparison of multi-decadal scale features.

\subsubsection{Natural warming analog}

As identified from the Mann and Jones (2003) record the earliest major warming of the last 2000 years in the Southern Hemisphere is AD 500 and for the Northern Hemisphere AD 800 (Fig. 3). Using the SD proxies for Southern Hemisphere atmospheric circulation, intensity of the Amundsen Sea Low and Southern Hemisphere
2, 327-355, 2006

Climate variability

over the last 2000

years

P. A. Mayewski and K. A. Maasch

Title Page

Abstract Introduction

Conclusions

Tables

References

Figures

14

$\rightarrow 1$

4

Back

Close

Printer-friendly Version

Interactive Discussion 
westerlies weakens as of AD 300 (Fig. 3). Using the GISP2 proxies for Northern Hemisphere atmospheric circulation, the Siberian High and Icelandic Low weaken following AD 200 and the westerlies by AD 400 (Fig. 3). Therefore onset for atmospheric circulation change in both hemispheres is earlier than temperature change and tem5 perature change is first in the Southern Hemisphere. From this natural analog for the phasing of warming and circulation change, temperature increase over the last few decades should follow change in atmospheric circulation and should also precede in the Southern Hemisphere. Instead recent temperature change precedes change in atmospheric circulation and occurs first in the Northern Hemisphere.

\subsubsection{Natural cooling analog}

As identified in the Mann and Jones (2003) temperature reconstructions major cooling occurs in the Southern Hemisphere $\sim A D 1000$ and in the Northern Hemisphere cooling onset is $\sim A D 1400$ (Fig. 3). Atmospheric circulation intensifies over the region of the Amundsen Sea Low by AD 800 before Southern Hemisphere temperature cooling and for the Southern Hemisphere westerlies by AD 1000. Atmospheric circulation intensifies over the region of the Siberian High just before the AD 1400 Northern Hemisphere cooling and at the same time as the cooling for the Icelandic Low and Northern Hemisphere westerlies. From the foregoing we assume that under conditions leading to naturally cooler temperatures Southern Hemisphere cooling leads Northern 20 Hemisphere cooling. In addition atmospheric circulation changes in both hemispheres precede or are coincident with temperature change.

\subsubsection{Current state of atmospheric circulation and temperature}

While examination of alpine glacier fluctuations (e.g., IPCC, 2001) shows that the temperature regime characterizing the onset of cooling AD 1000-1400 came to an end by AD 1850-1920, the atmospheric circulation systems discussed here are still in the range of variability established during the period AD 1000-1400 (Fig. 3). This is bet-
2, 327-355, 2006

Climate variability

over the last 2000

years

P. A. Mayewski and

K. A. Maasch

Title Page

Abstract

Introduction

Conclusions

References

Tables

Figures

14

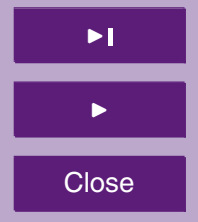

Back

Close 
ter illustrated by plotting the data in temperature-circulation phase space (Figs. 4-8, Table 1).

Figures 4-6 show the Northern Hemisphere temperature anomaly plotted against the GISP2 $\mathrm{Ca}^{+}, \mathrm{Na}^{+}$, and $\mathrm{K}^{+}$proxies for the strength of the Northern Hemisphere 5 westerlies, Icelandic Low, and Siberian High, respectively. In each figure the red dots represent data from AD 800-1400, blue dots AD 1401-1930, and green dots AD 19311985. The shaded red, blue and green boxes represent the mean \pm one standard deviation of the data for each of these time periods, respectively. The black arrows labeled 1980-1985 highlight data for the last 5 years of the record.Mean Northern 10 Hemisphere temperature for the period $A D 1401-1930$ is $0.10^{\circ} \mathrm{C}$ cooler compared to AD 800-1400. Average temperature for the period $1931-1985$ is $0.21^{\circ} \mathrm{C}$ higher than AD 800-1400 and $0.31^{\circ} \mathrm{C}$ higher than $A D$ 1401-1930, respectively. Comparison of atmospheric circulation for these same time periods reveals that the westerlies are stronger, and both the Icelandic Low and Siberian High are intensified from AD 1401151930 compared to AD 800-1400. During the AD 1931-1985 period while temperature reached unprecedented levels (even warmer than the AD 800-1400 period) all three proxy measures of atmospheric circulation remained at the levels they maintained for the period AD 1401-1930.

Figures 7 and 8 show the Southern Hemisphere temperature anomaly plotted 20 against the Siple Dome $\mathrm{Ca}^{+}$and $\mathrm{Na}^{+}$, proxies for the strength of the Southern Hemisphere westerlies and the Amundsen Sea Low, respectively. In each figure the red dots represent data from AD 500-1000, blue dots AD 1001-1930, and green dots AD 19311985. The shaded red, blue and green boxes represent the mean \pm one standard deviation of the data for each of these time periods, respectively. The black arrows labeled 25 1975-1980 highlight data for the last 5 years of the record.Mean Southern Hemisphere temperature during the period $A D 1001-1930$ is $0.11^{\circ} \mathrm{C}$ cooler compared to AD 5001000. Average temperature for the period $1931-1980$ is $0.03^{\circ} \mathrm{C}$ higher than $A D 500-$ 1000 and $0.12^{\circ} \mathrm{C}$ higher than AD 1001-1930, respectively. Comparison of atmospheric circulation for these same time periods reveals that the Southern Hemisphere wester-

2, 327-355, 2006

Climate variability over the last 2000

years

P. A. Mayewski and K. A. Maasch

Title Page

Abstract Introduction

Conclusions

Tables

References

Figures

14

$>$ I

4

Back

Close

Full Screen / Esc

Printer-friendly Version

Interactive Discussion 
lies are stronger between AD 1001-1930 than during the AD 500-1000 period and they are in a near maximum state of intensification for the period AD 1931-1980. The Amundsen Sea Low is intensified from AD 1001-1930 compared to AD 500-1000. The Amundsen Sea Low remained this intensified for the AD 1931-1980 period.

5 The Mann and Jones (2003) temperature reconstruction for the Southern Hemisphere, utilized in this study, suggests that recent temperatures are within the range of variability of the last $\sim 1000$ years. Although portions of the Antarctic Peninsula are warming dramatically (e.g., Vaughn et al., 2003; Turner et al., 2005) this is consistent with findings suggesting that the majority of Antarctica appears to be cooling over the 10 period 1979-1998 (e.g., Comiso, 2000; Kwok and Comisdo, 2002) and is largely unchanged in temperature over the preceding 200 years (based on recent analysis of eight ice core-instrument calibrated proxies of temperature ranging over East and West Antarctica, Schneider et al., 2006). Further, cooling over much of Antarctica during the last 1000 years is consistent with the range of variability identified in this study for the 15 Amundsen Sea Low and Southern Hemisphere westerlies over the same period.

If the generally cooler period of the last 6-10 centuries had truly ended as a naturally forced event by AD 1850-1920, the cooling would have been one of the shortest-lived abrupt climate change events in the 110000 year long GISP2 ice core record (Yang et al., 1997). Further, it is highly unlikely that such a short-lived event would be associated 20 with the most notable and perhaps largest magnitude event in the GISP2 Holocene atmospheric circulation record of the Icelandic Low, Siberian High, and Northern Hemisphere westerlies (Fig. 2). The sustained, and more importantly, enhanced retreat of glaciers and associated increase in Northern Hemisphere temperature during the last few decades is not consistent with the recent behaviour of these regional scale at25 mospheric circulation features or that of the Amundsen Sea Low and Southern Hemisphere westertlies records. To be in accord with the range of variability of these atmospheric circulation features, recent change in Northern Hemisphere temperature would be expected to be minimal to nil. Further if recent warming in the Northern Hemisphere is a consequence of purely natural forcing our results suggest that atmospheric circu-

2, 327-355, 2006

Climate variability over the last 2000 years

P. A. Mayewski and K. A. Maasch

Title Page

Abstract Conclusions

Tables References Figures

14

4

Back

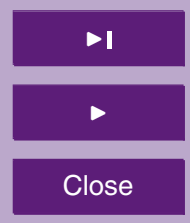

Full Screen / Esc

Printer-friendly Version

Interactive Discussion 
lation should have preceded temperature change and that circulation features in the middle to high latitudes of the Northern Hemisphere should be well within the range of the variability noted during the natural analog for warming described above.

\section{Concluding remarks}

5 Since the atmospheric circulation patterns examined in this study are still within the range of variability of the last 6-10 centuries it is expected that under such conditions modern temperatures should be relatively low or unchanged. On the contrary temperatures over the Northern Hemisphere (notably the Arctic (ACIA, 2004) have risen to the highest of the last 2000 years during the last few decades (Mann and Jones, 2003). The mismatch between the state of atmospheric circulation interpreted in our study and recent rise in Northern Hemisphere and portions of Southern Hemisphere temperature (notably the Antarctic Peninsula (Turner et al., 2005) is verification of the non-natural forcing of recent temperature. Further our finding that change in atmospheric circulation during onset of naturally warmer and colder periods precedes or 15 accompanies temperature change for both Northern and Southern Hemisphere middle to high latitudes is, in light of recent rise in Northern Hemisphere temperature leading change in atmospheric circulation, further verification of non-natural forcing of recent temperature. Onset of naturally forced change in climate occurs first in the Southern compared to Northern Hemisphere based on our annually resolved ice core records.

in Antarctic and Greenland ice cores based on matching $\mathrm{OH}_{4}$ records over the pein Antarctic and Greenland ice cores based on matching of $\mathrm{CH}_{4}$ records over the period 9000-57000 years ago (e.g., Brook et al., 2005). More importantly our results demonstrate an annually counted offset between Southern and Northern Hemisphere atmospheric circulation change of 400 years, AD 1000 and AD 1400, respectively, also noted in the independently dated Mann and Jones (2003) temperature reconstruction. The AD 1400 onset of change in atmospheric circulation was the most abrupt change of the last 9000 years for the Icelandic Low, Siberian High, and Northern Hemisphere
2, 327-355, 2006

Climate variability

over the last 2000

years

P. A. Mayewski and

K. A. Maasch

Title Page

Abstract

Introduction

Conclusions

References

Tables

Figures

14

$>1$

4

Back

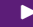

Close

Full Screen / Esc

Printer-friendly Version

Interactive Discussion 
westerlies. By analogy once the Southern Hemisphere responds more fully to greenhouse gas warming it could as it has in the past act as a "natural leader" or precursor for even more abrupt change in the Northern Hemisphere. As suggested by Barnett et al. (2005) and Hansen et al. (2005) Southern Hemisphere temperature rise may be lag5 ging in response to the Southern Ocean's vast capability for storage of anthropogenic source greenhouse gas induced heat. Our work suggests an additional cause, notably that the lagging of Southern Hemisphere temperature may be associated with underpinning by natural climate variability of the last 6-10 centuries. However, recent studies suggest that this situation may not last long since anthropogenically forced depletion of 10 stratospheric ozone and increased levels of $\mathrm{CO}_{2}$ may already be starting to impact the strength of the Southern Hemisphere westerlies and the polar vortex (Thompson and Solomon, 2002; Marshall et al., 2004; Shindell and Schmidt, 2004) in addition to temperatures in the Antarctic Peninsula (Turner et al., 2005). As suggested here, middle to high latitude atmospheric circulation is still within its naturally stormier state of the last

$156-10$ centuries. However, recent work also suggests that hurricane intensity in the middle to low latitudes is increasing in response to greenhouse gas induced surface-ocean warming (Barnett et al., 2005; Trenberth, 2005). As a consequence of the foregoing it could be expected that future climate will be characterized by even greater climate instability as the naturally stormier middle to high latitudes interface with greenhouse gas induced warming and intensified storms in low to middle latitudes.

Acknowledgements. Research support is from the National Science Foundation (OPP 9706921, OPP 0096305, and OPP 0096299) and the National Oceanic and Atmospheric Administration (NA04OAR4600179). We would like to thank the following for their contributions to this research: D. Meeker, Y. Yan, S. Kang, and E. Meyerson.

\section{References}

ACIA: Impacts of A Warming Arctic: Arctic Climate Impact Assessment, Cambridge University Press, Cambridge, UK, 952 p., 2004.
2, 327-355, 2006

Climate variability

over the last 2000

years

P. A. Mayewski and K. A. Maasch

Title Page

Abstract Introduction

Conclusions References

Tables Figures

14

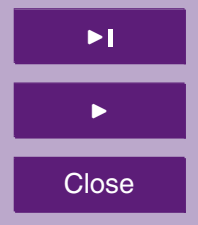

Back

Close

Full Screen / Esc

Printer-friendly Version

Interactive Discussion 
Barnett, T. P. Pierce, D. W., AchutaRao, K. M., Gleckler, P. J., Santer, B. D., Gregory, J. M., and Washington, W. M.: Penetration of human-induced warming into the world's oceans, Science, 309, 284-287, 2005.

Bertler, N. A. N., Barrett, P. J., Mayewski, P. A., Fogt, R. L., Kreutz, K. J., and Shulmeister, J.: El Niño suppresses Antarctic warming, Geophys. Res. Lett., 31, L15207, doi:10.1029/2004GL020749, 2004.

Biscaye, P. E., Grousset, F. E., Revel, M., Van der Gaast, S., Zielinski, G. A., Vaars, A., and Kukla, G.: Asian provenance of glacial dust (stage 2) in the Greenland Ice Sheet Project 2 ice core, Summit, Greenland, J. Geophys. Res., 102, 26 765-26 782, 1998.

10 Brook, E. J., White, J. W. C., Schilla, A. S. M., Bender, M. L., Barnett, B., Severinghaus, J. P., Taylor, K. C., Alley, R. B., and Steig, E. J.: Timing of millennial-scale climate change at Siple Dome, Antarctica, during the last glacial period, Quat. Sci. Rev., 1333-1343, 2005.

Comiso, J. C.: Variability and trends in Antarctic surface temperatures from in situ and satellite infrared measurements, J. Climate, 13, 1674-1696, 2000.

15 Denton, G. H. and Karlén, W.: Holocene climatic variations: Their pattern and possible cause, Quat. Res., 3, 155-205, 1973.

Goodwin, I. D., van Ommen, T. D., Curran, M. A. J., and Mayewski, P. A.: Mid-latitude climate variability in the south Indian Ocean and southwest Pacific regions since AD1300, Clim. Dyn., 22(8), 783-794, 2004.

20 Grootes, P. M. and Stuiver, M.: Oxygen 18/16 variability in Greenland snow and ice with $10^{-3}$ and $10^{5}$ year time resolution, J. Geophys. Res., 102, 26 455-26 470, 1997.

Grove, J. M.: The Little Ice Age, Methuen, New York, 498 pp, 1988.

Hall, J. S. and Wolff, E. W.: Causes of seasonal and daily variations in aerosol sea-salt concentrations at a coastal Antarctic station, Atmos. Environ., 32, 3669-3677, 1998.

25 Hansen, J., Nazarenko, L., Ruedy, R., Sato, M., Willis, J., Del Genio, A., Koch, D., Lacis, A., Lo, K., Menon, S., Novakov, T., Perlwitz, J., Russell, G., Schmidt, G. A., and Tausnev, N.: Earth's energy imbalance: Confirmation and implications, Science, 308, 1431-1434, 2005.

IPCC (Intergovernmental Panel on Climate Change): Climate Change 2001: The Scientific Basi, Contribution of Working Group I to the Third Assessment Report of the IPCC, edited by: Houghton, J. T., Ding, Y., Griggs, D. J., Noguer, M., van der Linden, P. J., Dai, X., Maskell, K., and Johnson, C. A., Cambridge, Cambridge University Press, 2001.

Kalnay, E., Kanamitsu, M., Kistler, R., Collins, W., Deaven, D., Gandin, L., Iredell, M., Saha, S., White, G., Woollen, J., Zhu, Y., and Leetmaa, A.: The NCEP/NCAR 40-Year Reanalysis

Climate variability over the last 2000

years

P. A. Mayewski and K. A. Maasch

Title Page

Abstract

Conclusions

Tables References Figures

14

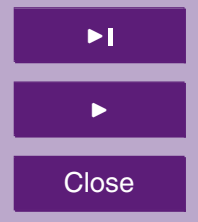

Back

Close

Full Screen / Esc

Printer-friendly Version

Interactive Discussion 
Project, Bull. Amer. Meteorol. Soc., 77(3), 437-471, 1996.

Kaspari, S., Mayewski, P. A., Dixon, D., Sneed, S. B., and Handley, M. J.: Sources and transport pathways for marine aerosol species into West Antarctica, Ann. Glaciol., 42, 1-9, 2005.

Kreutz, K. J., Mayewski, P. A., Meeker, L. D., Twickler, M. S., Whitlow, S. I., and Pittalwala, I.

$5 \quad$ I.: Bipolar changes in atmospheric circulation during the Little Ice Age, Science, 277, 12941296, 1997.

Kreutz, K. J. and Mayewski, P. A.: Survey of Antarctic surface snow glaciochemistry, Antarctic Science, 11(1), 105-118, 1999.

Kreutz, K. J., Mayewski, P. A., Pittalwala, I. I., Meeker, L. D., Twickler, M. S., and Whitlow, S. I.: Sea level pressure variability in the Amundsen Sea region inferred from a West Antarctic glaciochemical record, J. Geophys. Res.-Atmos., 105(D3), 4047-4059, 2000.

Kwok, R. and Comiso, J. C.: Spatial patterns of temperature variability in Antarctic surface temperature: Connections to the Southern Hemisphere Annular Mode and Southern Oscillation, Geophys. Res. Lett., 29, 1705, 2002.

Legrand, M. and Mayewski, P. A.: Glaciochemistry of polar ice cores: A review, Rev. Geophys., 35, 219-143, 1997.

Mann, M. E. and Jones, P. D.: Global surface temperatures over the past two millennia, Geophys. Res. Lett., 30(15), 1820-1824, 2003.

Marshall, G. J., Stott, P. A., Turner, J., Connolley, W. M., King, J. C., and Lachlan-Cope, T. A.: Causes of exceptional atmospheric circulation changes in the Southern Hemisphere, Geophys. Res. Lett., 31, L14205, doi:10.1029/2004GL019952, 2004.

Masson-Delmotte, V., Jouzel, J., Landais. A., Stievenard, M., Johnsen, S. J., White, J. W. C., Werner, M., Sveinbjornsdottir, A., and Fuhrer, K.: GRIP deuterium excess reveals rapid and orbital-scale changes in Greenland moisture origin, Science, 309, 118-121, 2005.

Mayewski, P. A., Meeker, L. D., Morrison, M. C. Twickler, M. S., Whitlow, S., K. K. Ferland, D., Meese, A., Legrand, M. R., and Steffenson, J. P.: Greenland ice core "signal" characteristics: An expanded view of climate change, J. Geophys. Res., 98(D7), 12 839-12 847, 1993.

Mayewski, P. A., Meeker, L. D., Twickler, M. S., Whitlow, S. I., Yang, Q., Lyons, W. B., and Prentice, M.: Major features and forcing of high latitude northern hemisphere atmospheric 30 circulation over the last 110000 years, J. Geophys. Res., 102(C12), 26 345-26 366, 1997.

Mayewski, P. A., Rohling, E., Stager, C., Karlén, K., Maasch, K., Meeker, L. D., Meyerson, E., Gasse, F., van Kreveld, S., Holmgren, K., Lee-Thorp, J., Rosqvist, G., Rack, F., Staubwasser, M., Schneider, R., and Steig, S.: Holocene climate variability, Quat. Res., 62, 243-255,
2, 327-355, 2006

\section{Climate variability}

over the last 2000

years

P. A. Mayewski and K. A. Maasch

Title Page

Abstract

Introduction

Conclusions

References

Tables

Figures

14

4

Back

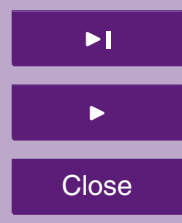

Full Screen / Esc

Printer-friendly Version

Interactive Discussion 
2004.

Mayewski, P. A., Maasch, K. A., White, J. W. C. Meyerson, E., Goodwin, I., Morgan, V. I., van Ommen, T., Curran, M. A. J., Souney, J., and Kreutz, K.: A 700 year record of Southern Hemisphere extra-tropical climate variability, Ann. Glaciol., 39, 127-132, 2005.

5 Mayewski, P. A., Maasch, K., Yan, Y., Kang, S., Meyerson, E., Sneed, S., Kaspari, S., Dixon, D., Morgan, V., van Ommen, T., and Curran, M.: Solar forcing of the polar atmosphere, Ann. Glaciol., 41, 147-154, 2006.

Meeker, L. D., Mayewski, P. A., Twickler, M. S. Whitlow, S. I., and Meese, D. A.: A 110,000 year long history of change in continental biogenic source strength and related atmospheric circulation, J. Geophys. Res., 102(C12), 26 489-26 504, 1997.

Meeker, L. D. and Mayewski, P. A.: A 1400 year long record of atmospheric circulation over the North Atlantic and Asia, The Holocene, 12(3), 257-266, 2002.

Meese, D. A., Alley, R. B., Gow, A. J., Grootes, P., Mayewski, P. A., Ram, M., Taylor, K. C., Waddington, E. D., and Zielinski, G.: The accumulation record from the GISP2 core as an indicator of climate change throughout the Holocene, Science, 266, 1680-1682, 1994.

Meese, D. A., Gow, A. J., Alley, R. B., Zielinski, G. A., Grootes, P. M., Ram, M., Taylor, K. C., Mayewski, P. A., and Bolzan, J. F.: The GISP2 depth-age scale: Methods and results, J. Geophys. Res., 102(C12), 26 411-26 424, 1997.

Meyerson, E. A., Mayewski, P. A., Whitlow, S. I., Meeker, L. D., and Kreutz, K. J., and Twickler, M. S.: The extratropical expression of ENSO recorded in a South Pole glaciochemical time series, Ann. Glaciol., 35, 430-436, 2002.

Moberg, A., Sonechiden, D. M., Holmgren, K., Datsenko, M. N., and Karlén, W.: Highly variable Northern Hemisphere temperatures reconstructed from low- and high-resolution proxy data, Nature, 433, 613-17, 2005.

Mulvaney, R. and Wolff, E.: Spatial variability of the major chemistry of the Antarctic ice sheet, Ann. Glaciol., 20, 440-447, 1994.

Noone, D. and Simmonds, I.: Annular variations in moisture transport mechanisms and the abundance of 180 in Antarctic snow, J. Geophys. Res., 107(D24), 4742, doi:10.1029/2002JD002262, 2002.

30 O’Brien, S. R., Mayewski, P. A., Meeker, L. D., Meese, D. A., Twickler, M. S., and Whitlow, S. I.: Complexity of Holocene climate as reconstructed from a Greenland ice core, Science, 270, 1962-1964, 1996.

Piexoto, J. P. and Oort, A. H.: Physics of Climate, American Institute of Physics, New York, NY,

Climate variability over the last 2000

years

P. A. Mayewski and K. A. Maasch

Title Page

Abstract Introduction

Conclusions References

Tables Figures

14

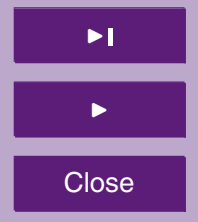

Back

Close

Full Screen / Esc

Printer-friendly Version

Interactive Discussion 
1992.

Schneider, D. P., Steig, E. J., van Ommen, T. D., Bitz, C. M., Dixon, D., Mayewski, P. A., and Jones, J. M.: A 200-year climate reconstruction for the Antarctic continent, Geophys. Res. Lett., in press, 2006.

5 Shindell, D. T. and Schmidt, G. A.: Southern hemisphere climate response to ozone changes and greenhouse gas increases, Geophys. Res. Lett., 31., L18209, doi:10.1029/2004GL020724, 2004.

Soon, W. and Baliunas, S.: Proxy climatic and environmental changes of the past 1000 years, Clim. Res., 23, 89-110, 2003.

10 Souney, J., Mayewski, P. A., Goodwin, I., Morgan, V., and van Ommen, T.: A late Holocene climate record from Law Dome, East Antarctica, J. Geophys. Res., 107(D22), 4608-4617, 2002.

Taylor, K., Alley, R. B., Meese, D. A., Spencer, M., Brook, E., Zielinski, G., Nishiizumi, K., Meyerson, E., Mayewski, P. A., Lamorey, G., Kurbatov, A., Gow, T., Finkel, R., and Dunbar, N.: Dating the Siple Dome, Antarctic a ice core by manual and computer interpretation of annual layering, J. Glaciol., 50(170), 453-461, 2004.

Thompson, D. W. J. and Wallace, J. M.: Annular modes in extratropical circulation, Part 1: Month-to-month variability, J. Climate, 13, 1000-1016, 2000.

Thompson, D. W. J. and Solomon, S.: Interpretation of recent southern hemisphere climate change, Science, 296, 895-899, 2002.

Trenberth, K. E. and Paolino Jr., D. A.: The Northern Hemisphere sea-level pressure data set: Trends, errors and discontinuities, Mon. Wea. Rev., 106, 855-872, 1980.

Trenberth, K.: Uncertainty in hurricanes and global warming, Science, 308, 1753-1754, 2005.

Turner, J., Colwell, S. R., Marshall, G. J., Lachlan-Cope, T. A., Carleton, A. M., Jones, P. D., Lagun, V., Reid, P. A., and Agovkina, S. I.: Antarctic climate change during the last 50 years, Int. J. Climatol., 25, 279-294, 2005.

Vaughan, D. G., Marshall, G. J., Connelly, W. M., Parkinson, C., Mulvaney, R., Hodgson, D. A., King, J. C., Pudsey, C. J., and Turner, J.: Recent rapid regional climate warming on the Antarctic Peninsula, Clim. Change, 60, 243-274, 2003.

Werner, M. and Heinmann, M.: Modeling interannual variability of water isotopes in Greenland and Antarctica, J. Geophys. Res., 107(D1), 4001, doi:10.1029/2001JD900253, 2002.

Whitlow, S., Mayewski, P. A., and Dibb, J. E.: A comparison of major chemical species input timing and accumulation at South Pole and Summit Greenland, Atmos. Environ., 26A(11),

Climate variability over the last 2000

years

P. A. Mayewski and K. A. Maasch

\section{Title Page}

Abstract Introduction

Conclusions References

Tables Figures

14

4

Back

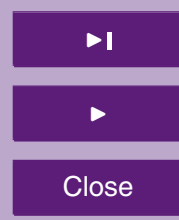

Full Screen / Esc

Printer-friendly Version

Interactive Discussion 
2045-2054, 1992.

Yan, Y., Mayewski, P. A., Kang, S., and Meyerson, E.: An ice core proxy for Antarctic circumpolar wind intensity, Ann. Glaciol., 41, 121-130, 2006.

Yang, Q., Mayewski, P. A., Whitlow, S. I., and Twickler, M. S.: Major features of glaciochemistry over the last 110,000 years in the GISP2 ice core, J. Geophys. Res., 102, 23289-23299, 1997.

Zhang, X. Y., Arimoto, R., An, Z. S., Chen, T., Zhang, G. Y., Shu, G., and Wang, X. F.: Atmospheric trace elements over source regions of Chinese dust: Concentrations, sources and atmospheric input to the Loess plateau, Atmos. Environ., 27A, 2051-2067, 1993.
2, 327-355, 2006

\section{Climate variability}

over the last 2000

years

P. A. Mayewski and

K. A. Maasch

Title Page

Abstract

Introduction

Conclusions

References

Tables

Figures

14

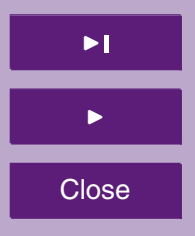

Back

Full Screen / Esc

Printer-friendly Version

Interactive Discussion 
Table 1. Mean \pm one standard deviation for climate records shown in Fig. 3 calculated for each of the time spans marked by the vertical lines.

\begin{tabular}{ccccc}
\hline Years AD & $\begin{array}{c}\text { NHem temperature } \\
\text { anomaly }\left({ }^{\circ} \mathrm{C}\right)\end{array}$ & $\begin{array}{c}\mathrm{Ca}^{+2}(\mathrm{ppb}) \text { proxy } \\
\text { for westerlies }\end{array}$ & $\begin{array}{c}\mathrm{Na}^{+}(\mathrm{ppb}) \text { proxy } \\
\text { for Icelandic Low }\end{array}$ & $\begin{array}{c}\mathrm{K}^{+}(\mathrm{ppb}) \text { proxy } \\
\text { for Siberian High }\end{array}$ \\
\hline $800-1400$ & $-0.22 \pm 0.07$ & $5.74 \pm 0.92$ & $4.5 \pm 0.60$ & $0.88 \pm 0.21$ \\
$1401-1930$ & $-0.32 \pm 0.07$ & $8.01 \pm 1.42$ & $5.89 \pm 1.28$ & $1.82 \pm 0.87$ \\
$1931-1985$ & $-0.01 \pm 0.06$ & $7.65 \pm 1.04$ & $4.95 \pm 0.57$ & $1.12 \pm 0.12$ \\
\hline Years AD & $\begin{array}{c}\text { SHem temperature } \\
\text { anomaly }\left({ }^{\circ} \mathrm{C}\right)\end{array}$ & $\begin{array}{c}\mathrm{Ca}^{+2}(\mathrm{ppb}) \text { proxy } \\
\text { for westerlies }\end{array}$ & $\begin{array}{c}\mathrm{Na}^{+}(\mathrm{ppb}) \text { proxy } \\
\text { for Amundsen Sea Low }\end{array}$ \\
\hline $500-1000$ & $-0.13 \pm 0.14$ & $4.13 \pm 0.51$ & $101.52 \pm 14.64$ & \\
$1001-1930$ & $-0.22 \pm 0.13$ & $6.62 \pm 1.66$ & $143.48 \pm 28.16$ & \\
$1931-1980$ & $-0.10 \pm 0.07$ & $9.47 \pm 0.85$ & $147.13 \pm 19.97$ & \\
\hline
\end{tabular}

\section{Climate variability over the last 2000 years}

P. A. Mayewski and K. A. Maasch

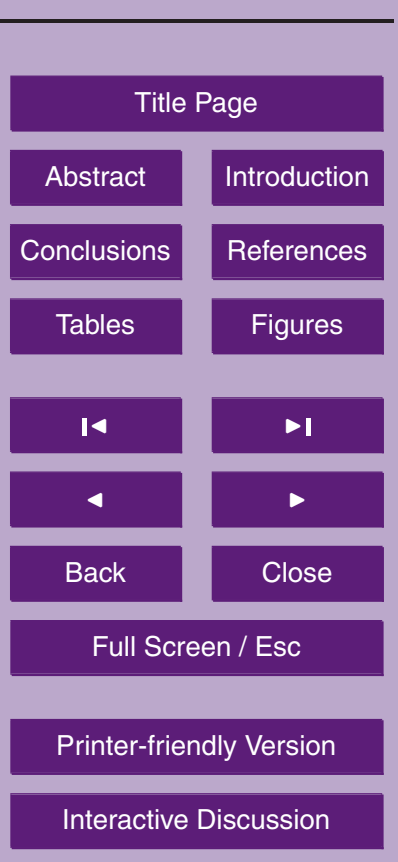




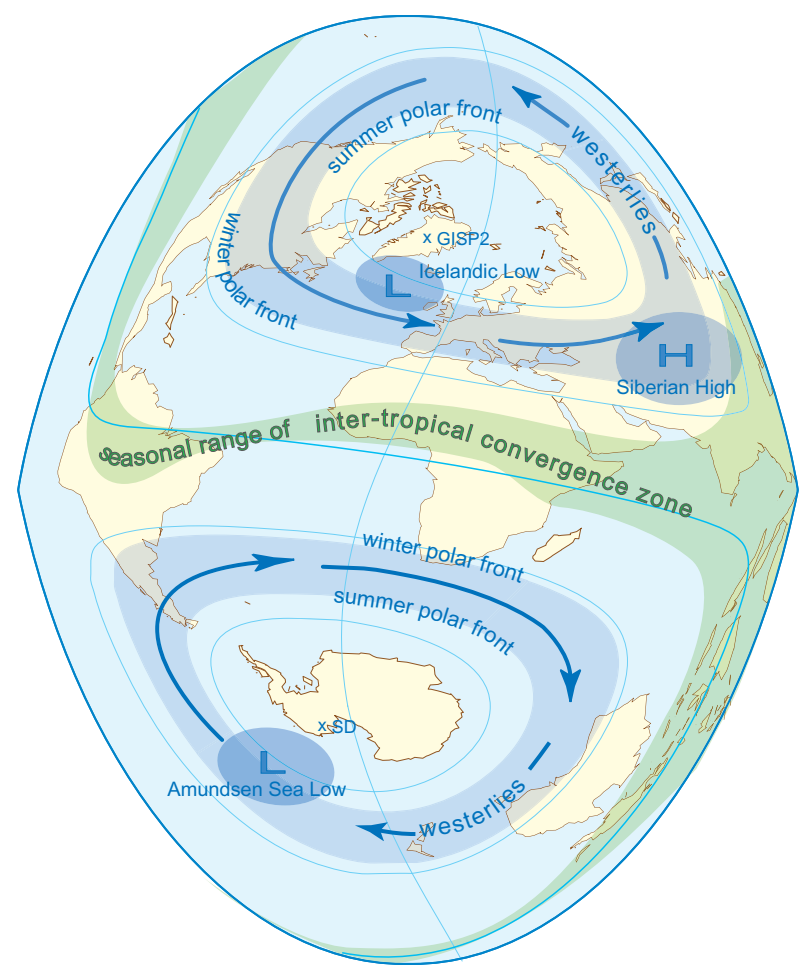

Fig. 1. GISP2 (GISP2) and Siple Dome (SD) ice core locations, idealized position of the winter and summer polar fronts in both hemispheres and the ITCZ, and the idealized location of atmospheric circulation features (in blue) referred to in this study (Icelandic Low, Siberian High, Northern and Southern Hemisphere westerlies, and Amundsen Sea Low).
2, 327-355, 2006

Climate variability

over the last 2000

years

P. A. Mayewski and

K. A. Maasch

Title Page

Abstract

Introduction

Conclusions

References

Tables

Figures
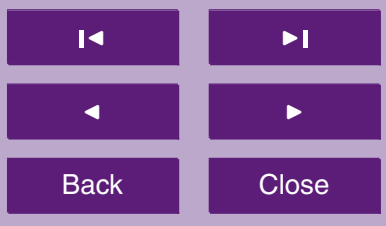

Full Screen / Esc

Printer-friendly Version

Interactive Discussion 


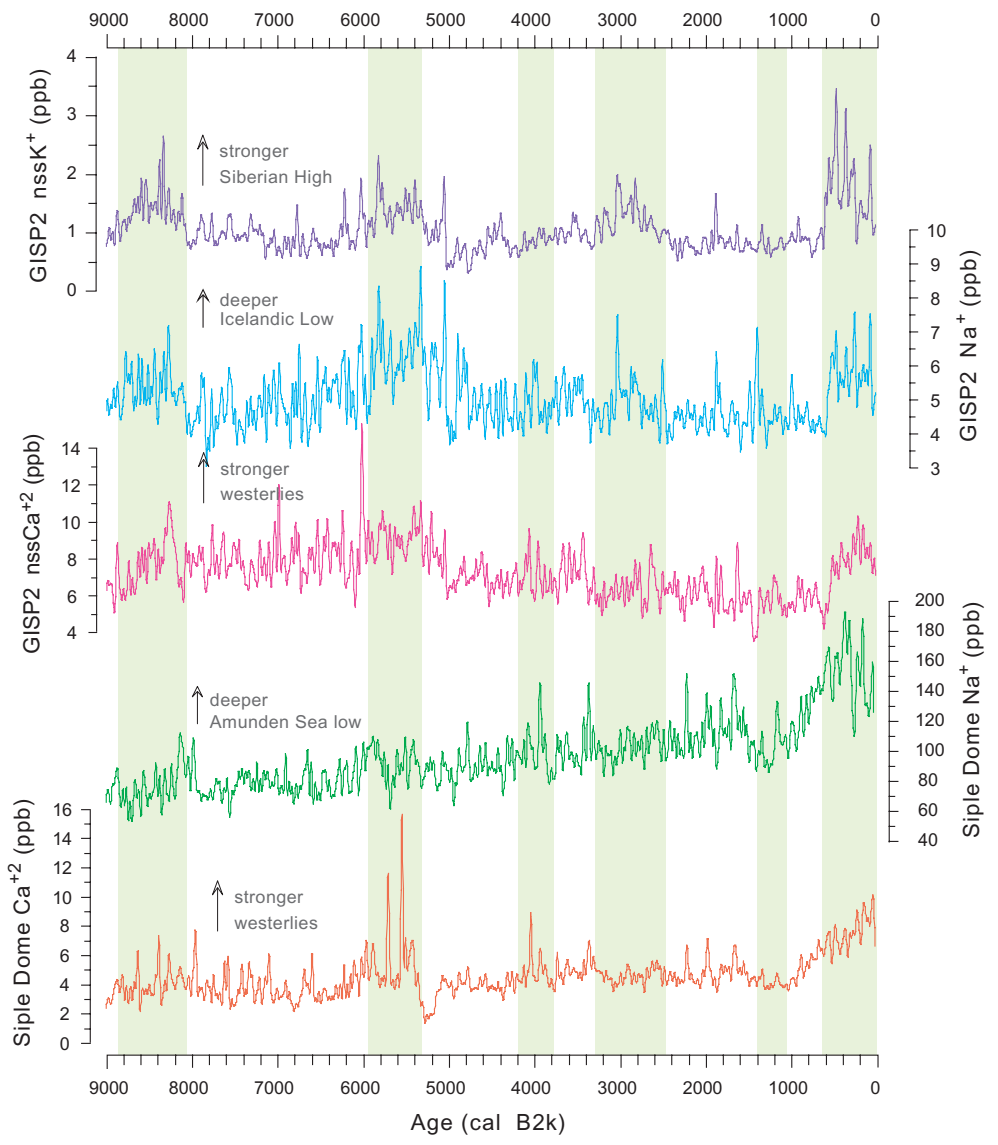

2, 327-355, 2006

Climate variability over the last 2000 years

P. A. Mayewski and K. A. Maasch

Title Page

Abstract Introduction

Conclusions

References

Tables

Figures

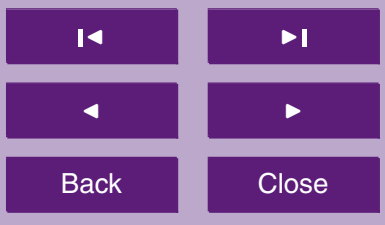

Full Screen / Esc

Printer-friendly Version

Interactive Discussion 


\section{Climate variability over the last 2000 years}

Fig. 2. The last 9000 years of GISP2 $\left(\mathrm{Na}^{+}, \mathrm{nssK}^{+}, \mathrm{nssCa}^{++}\right)$and $\mathrm{SD}\left(\mathrm{Na}^{+}, \mathrm{Ca}^{++}\right)$at the same smoothing (less than 30-yr signal removed) with highlighting of major Holocene abrupt climate change events (shaded periods) identified from a synthesis of $\sim 50$ paleoclimate records (Mayewski et al., 2004). Changes in GISP2 $\mathrm{Na}^{+}$are correlated with December-JanuaryFebruary surface pressure over the Icelandic Low such that increases (decreases) in $\mathrm{Na}^{++}$ coincide with decreases (increases) in pressure over this region. Increases (decreases) in GISP2 nssK $^{+}$are correlated with March-April-May increases (decreases) in pressure over the region of the Siberian High. Changes in GISP2 $\mathrm{nssCa}^{++}$are positively associated with September-October-November changes in intensity of the westerlies. Increases (decreases) in $\mathrm{SD} \mathrm{Na}{ }^{+}$are correlated with decreases (increases) in September-October-November surface pressure over the region of the Amundsen Sea Low. Changes in $\mathrm{SD} \mathrm{Ca}^{++}$are positively correlated with changes in the September-October-November (SON) surface mean zonal wind surrounding Antarctica, most notably the region close to $40-50^{\circ} \mathrm{S}$ in the Indian and Pacific Oceans.
P. A. Mayewski and K. A. Maasch

\section{Title Page}

\section{Abstract}

Conclusions

Tables

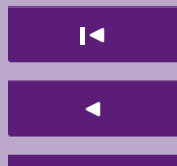

Back

\section{Introduction}

References

Figures

$>1$

$\rightarrow$

Close
Full Screen / Esc

Printer-friendly Version

Interactive Discussion 


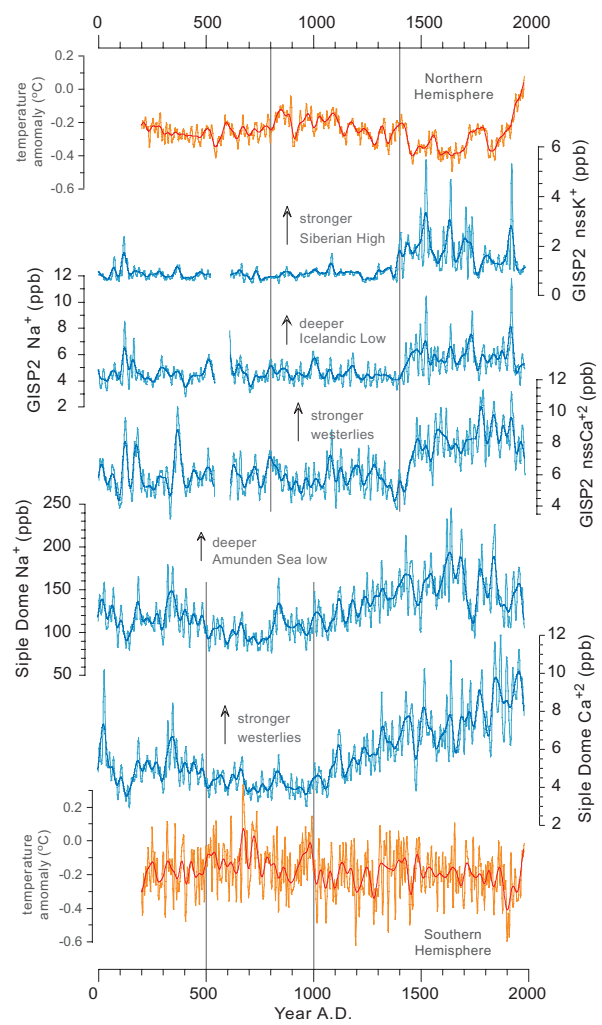

Fig. 3. Northern and Southern Hemisphere reconstructed temperatures (in red from Mann and Jones, 2003) and ice core reconstructed atmospheric circulation systems (in blue) referred to in this study (Icelandic Low, Siberian High, Northern and Southern Hemisphere westerlies, and Amundsen Sea Low). Data is presented with less than 10-yr signal (light line) extracted to approximate the original annual to multi-annual series and with the less than 30-yr signal (dark line) extracted series to facilitate examination at decadal scales. Vertical lines refer to onset for temperature change referred to in the text.
2, 327-355, 2006

Climate variability over the last 2000

years

P. A. Mayewski and K. A. Maasch

Title Page
Abstract

Conclusions

Tables

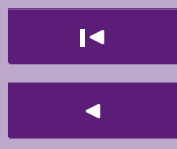

Back

\section{Introduction}

References

Figures

$\Delta$

Close
Full Screen / Esc

Printer-friendly Version

Interactive Discussion 


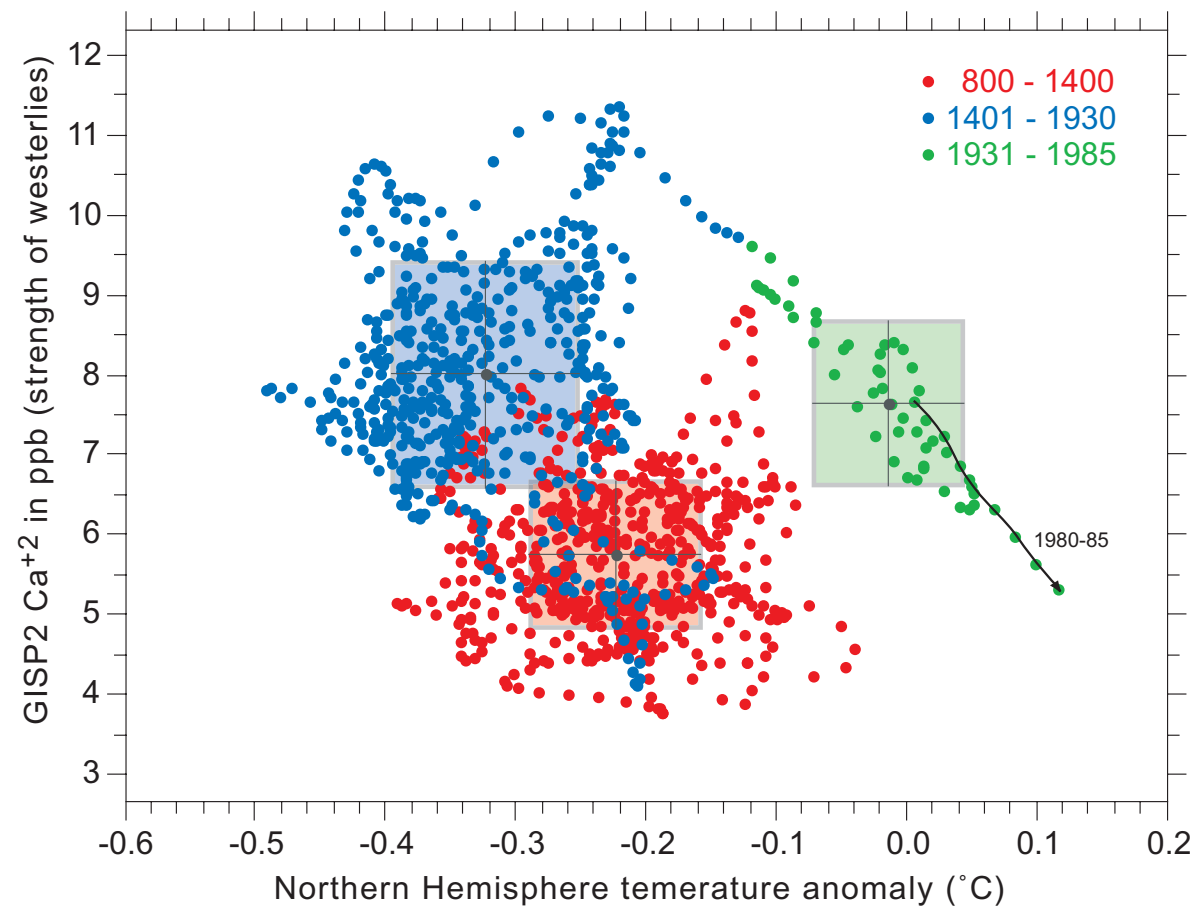

Fig. 4. Phase diagram for Northern Hemisphere temperature versus ice core proxy for Northern Hemisphere westerlies (shown in Fig. 3, light lines). Red dots are data from 800-1400 AD, blue dots 1401-1930 AD, and green dots 1931-1985 AD. The shaded red, blue and green boxes represent the mean \pm one standard deviation of the data for each these time periods, respectively. The black arrow labelled 1980-1985 highlights data for the last 5 years of the record.

$2,327-355,2006$

\section{Climate variability over the last 2000 years}

P. A. Mayewski and K. A. Maasch

\section{Title Page}

\section{Abstract}

Conclusions

Tables

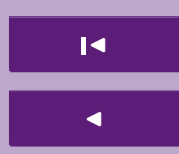

Back
Introduction

References

\section{Figures}

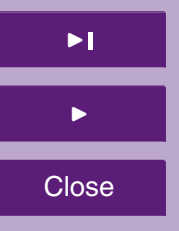

Full Screen / Esc

Printer-friendly Version

Interactive Discussion 


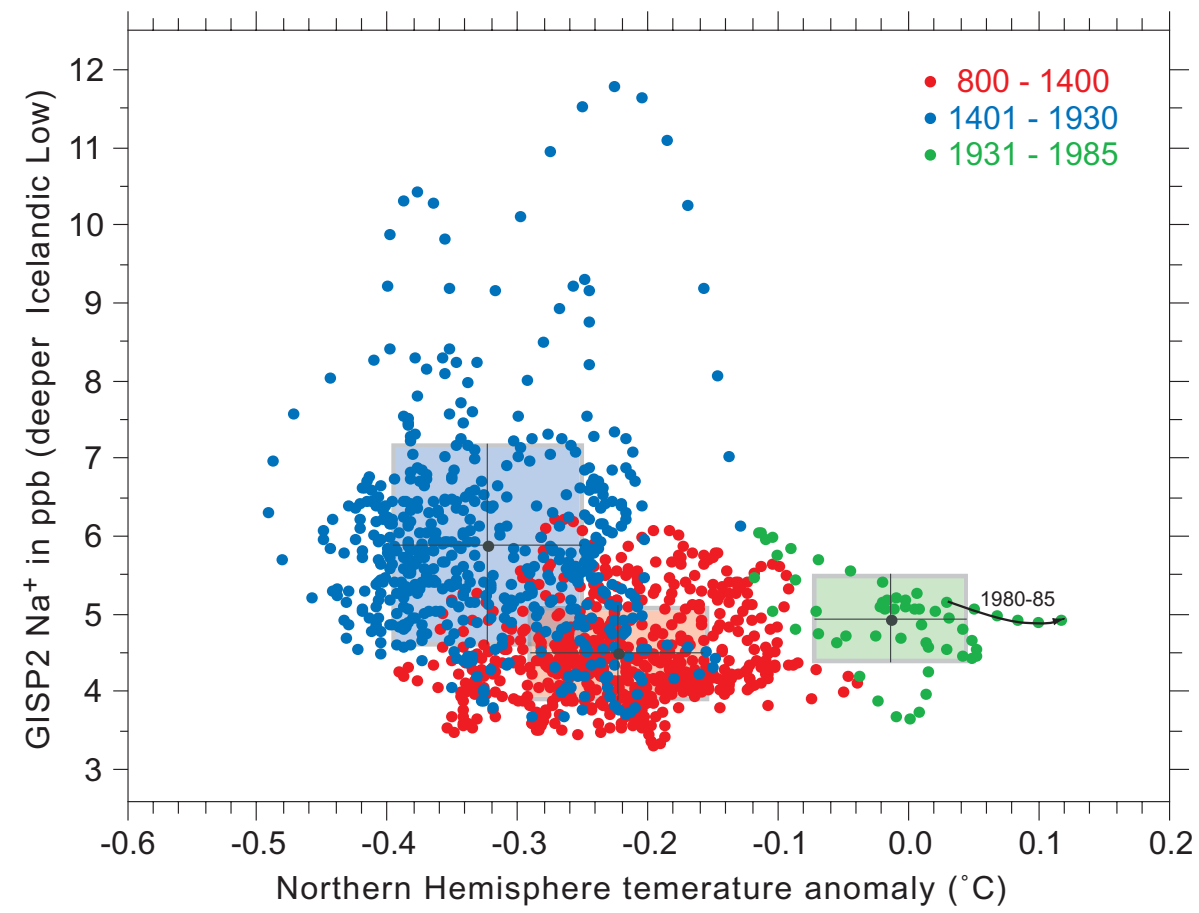

Fig. 5. Same as Fig. 4 except for Northern Hemisphere temperature versus ice core proxy for Icelandic Low.

\section{Climate variability} over the last 2000 years

P. A. Mayewski and K. A. Maasch

Title Page

Abstract Introduction

Conclusions

References

Tables Figures
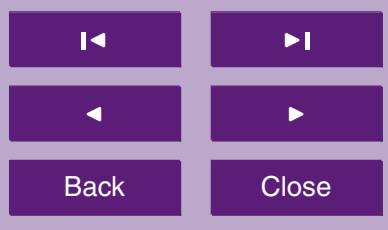

Full Screen / Esc

Printer-friendly Version

Interactive Discussion 
2, 327-355, 2006

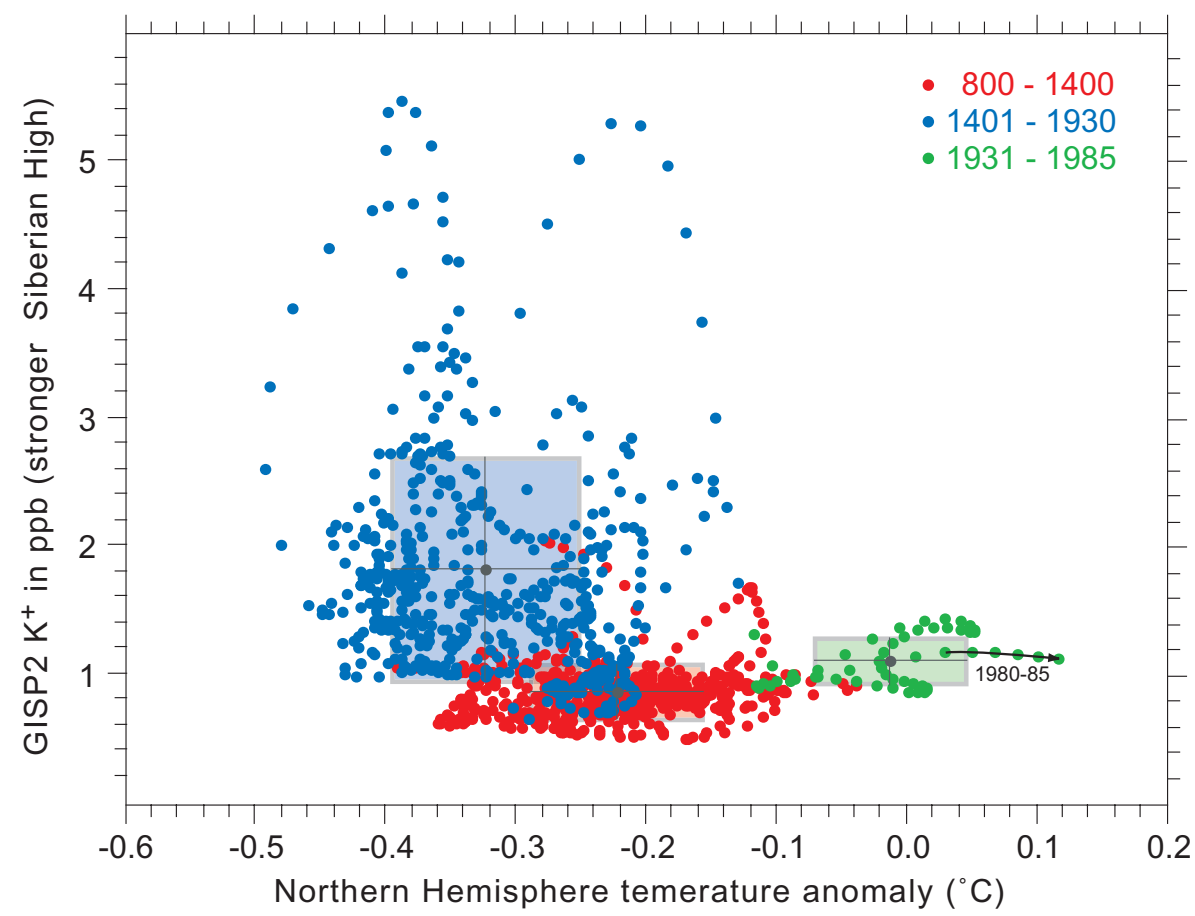

\section{Climate variability} over the last 2000 years

\section{P. A. Mayewski and} K. A. Maasch

Title Page

Abstract

Conclusions
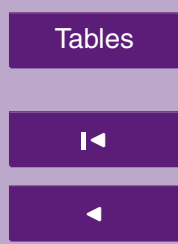

Back

Fig. 6. Same as Fig. 4 except for Northern Hemisphere temperature versus ice core proxy for Siberian High.

\section{Full Screen / Esc}

Printer-friendly Version

Interactive Discussion 


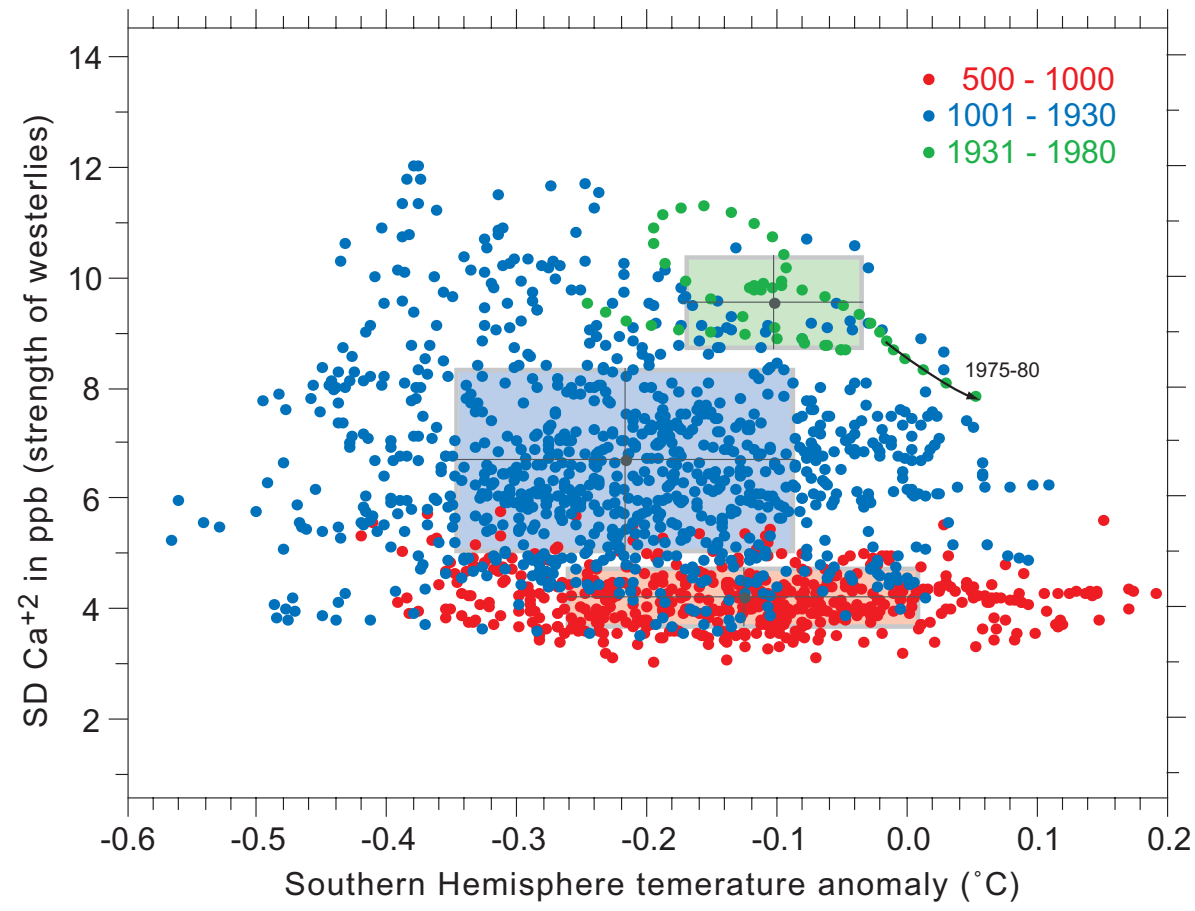

Fig. 7. Phase diagram for Southern Hemisphere temperature versus ice core proxy for Sourthern Hemisphere westerlies (shown in Fig. 3, light lines). Red dots are data from 500-1000 AD, blue dots 1001-1930 AD, and green dots 1931-1985 AD. The shaded red, blue and green boxes represent the mean \pm one standard deviation of the data for each these time periods, respectively. The black arrow labelled 1975-1980 highlights data for the last 5 years of the record.

2, 327-355, 2006

Climate variability over the last 2000 years

P. A. Mayewski and K. A. Maasch

Title Page

Abstract

Conclusions

Tables

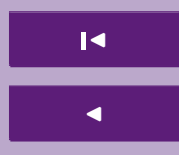

Back

\section{Full Screen / Esc}

Printer-friendly Version

Interactive Discussion 


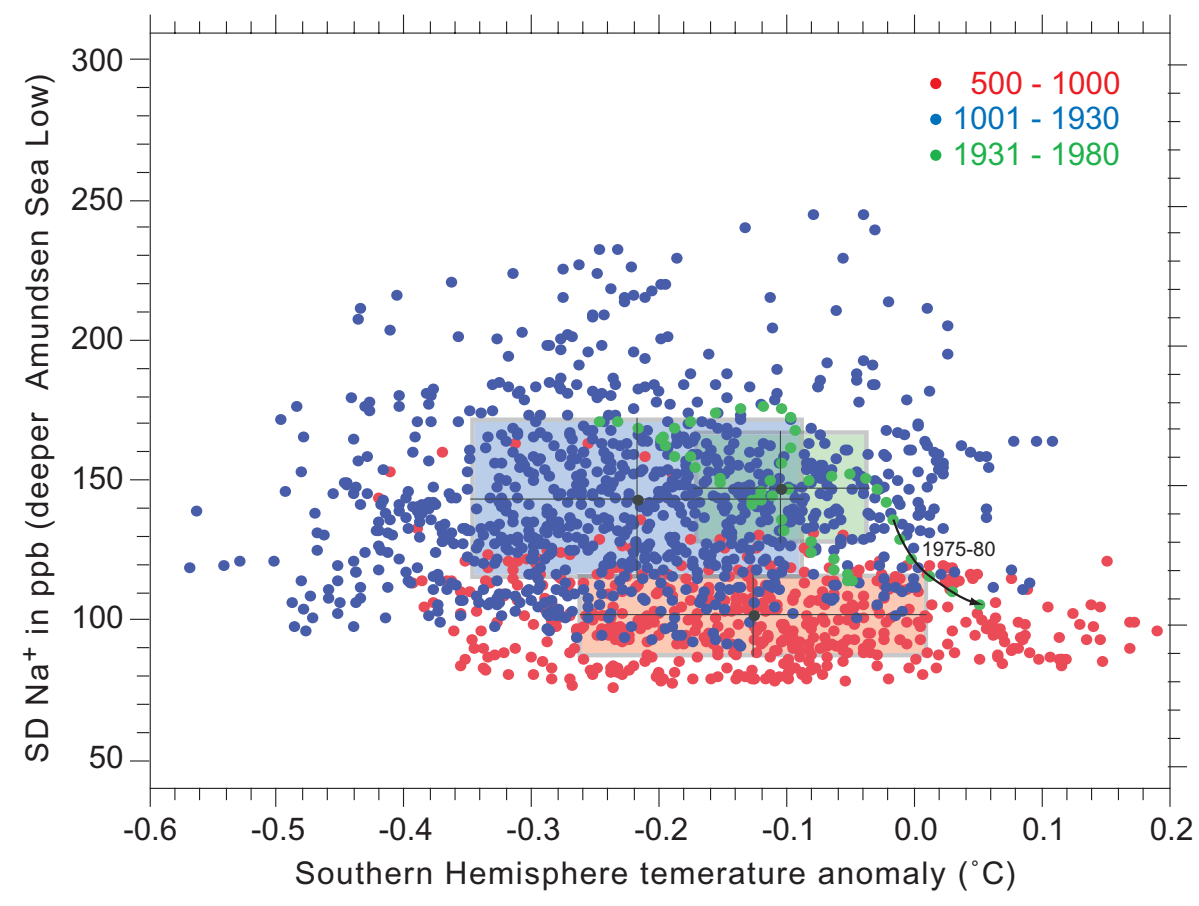

Fig. 8. Same as Fig. 4 except for Southern Hemisphere temperature versus ice core proxy for Amundsen Sea Low.
Climate variability over the last 2000 years

P. A. Mayewski and K. A. Maasch

Title Page

Abstract Introduction

Conclusions

References

Tables Figures
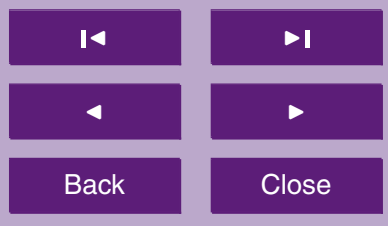

Full Screen / Esc

Printer-friendly Version

Interactive Discussion 